ROBERT E. HALL

University of California (Berkeley)

\title{
Recent Increases in Unemployment
}

AFTER A FALSE ALARM last fall, the long-predicted increase in unemployment began with unexpected sharpness at the beginning of 1970. In March, the last month for which data are available, the number of unemployed was almost a million higher than the level of March 1969. The purpose of this short report is to examine the pattern of unemployment last fall and winter. The data presented here are drawn exclusively from the monthly household survey conducted by the Bureau of the Census and compiled by the Department of Labor. Although only about one household in a thousand is included in it, the survey provides a uniform and complete view of the U.S. labor market. Data from other sources-relating to unemployment insurance and payrolls - are seriously incomplete in their coverage, and may therefore present a misleading picture in periods of rapid change.

Data on unemployment by color are presented in Table 1. Nonwhites have fared relatively better than whites in the period from January through March 1970. Between the first quarter of 1969 and the first quarter of 1970, white unemployment rose 31 percent and nonwhite unemployment only 16 percent. Nonwhites had a much less favorable experience in the fall of 1967: In October, when total unemployment had risen by about 500,000 over the level of October 1966, the percentage increase in nonwhite unemployment over a year earlier was actually greater than that for white unemployment-24 percent against 19 percent. But the favorable experience of nonwhites in the first quarter of 1970 is insufficient evidence for concluding that job security has substantially improved for minority 
groups. The sharp jump in unemployment this winter has been concentrated in selected industrial sectors. Thus the racial composition of unemployment can be explained in conventional terms by the underrepresentation of blacks and other nonwhites in the labor forces of the small group of cyclically sensitive industries that have recently been contracting.

\section{Table 1. Unemployment, by Color, August 1968-March 1969 and August 1969-March 1970}

Thousands of persons, without seasonal adjustment

\begin{tabular}{lcccccc}
\hline \multicolumn{1}{c}{ Month } & \multicolumn{2}{c}{ Total } & \multicolumn{2}{c}{ White } & \multicolumn{2}{c}{ Nonwhite } \\
\hline & 1968 & 1969 & 1968 & 1969 & 1968 & 1969 \\
August & 2,772 & 2,869 & 2,196 & 2,257 & 575 & 613 \\
September & 2,606 & 2,958 & 2,083 & 2,400 & 523 & 558 \\
October & 2,511 & 2,839 & 1,966 & 2,302 & 544 & 537 \\
November & 2,577 & 2,710 & 2,020 & 2,160 & 557 & 550 \\
December & 2,419 & 2,628 & 1,917 & 2,155 & 501 & 473 \\
& 1969 & 1970 & 1969 & 1970 & 1969 & 1970 \\
January & 2,876 & 3,406 & 2,298 & 2,803 & 578 & 603 \\
February & 2,923 & 3,794 & 2,379 & 3,127 & 544 & 668 \\
March & 2,746 & 3,733 & 2,214 & 3,082 & 532 & 651 \\
\hline
\end{tabular}

Source: Employment and Earnings, various issues.

Changes in the racial composition of unemployment in recent months resemble those in the recession of 1960-61, as shown in Table 2. In both instances, the percentage change in unemployment is greater among whites than among nonwhites. ${ }^{1}$ Over the whole business cycle, the relationship between the unemployment rates for whites and nonwhites remains about the same, ${ }^{2}$ but whites, especially adult males, are the first to suffer from a sharp increase in unemployment.

Second, it appears a serious mistake to regard the rise in seasonally adjusted unempioyment of September and October 1969 as the reflection of a smooth and general declining trend in the demand for labor. As shown in Table 3, unemployment was about 350,000 greater in September and

1. The racial composition of unemployment seems to have behaved roughly the same way in the sharper recession of 1957-58. The substantial revisions in the definitions used in the household survey starting in 1957 make it impossible to compare 1957 with 1956.

2. For recent evidence, see Paul M. Ryscavage, "Impact of Higher Unemployment on Major Labor Force Groups," Monthly Labor Review, Vol. 93 (March 1970), pp. 21-25. 
October than a year earlier; yet the number of persons unemployed because they had lost their jobs was virtually unchanged. The whole increase in unemployment came from new entrants and reentrants into the labor force, and from those who voluntarily left their jobs. ${ }^{3}$ Reentrants into the labor force accounted for over half the total increase; among them probably the majority were married women, because 1969 saw an acceleration in the trend toward higher participation by this group in the labor force. The demand for labor apparently remained high throughout this period, since by the November survey, unemployment was close to its level of November 1968 in every group. The drop in the seasonally adjusted unem-

\section{Table 2. Percentage Change in Unemployment, by Color, from Same Month in Preceding Year, November 1960-March 1961 and November 1969-March 1970}

Without seasonal adjustment

\begin{tabular}{lcccc}
\hline \multicolumn{1}{c}{ Month } & \multicolumn{2}{c}{ White } & \multicolumn{2}{c}{ Nonwhite } \\
\hline & 1960 from 1959 & 1969 from 1968 & 1960 from 1959 & 1969 from 1968 \\
November & 8.0 & 6.9 & 17.7 & -1.3 \\
December & 30.1 & 12.4 & 16.0 & -5.6 \\
& 1961 from 1960 & 1970 from 1969 & 1961 from 1960 & 1970 from 1969 \\
January & 31.8 & 22.0 & 22.1 & 4.3 \\
February & 46.0 & 31.4 & 41.7 & 22.8 \\
March & 33.1 & 39.2 & 21.5 & 22.4 \\
\hline
\end{tabular}

Source: Employment and Earnings, various issues.

ployment rate that took place in November was widely regarded as an aberration; this analysis suggests that, on the contrary, it was the increase in September and October that was an artifact, in the sense that it did not originate in a reduction in the demand for labor.

Table 3 also shows how the situation changed in the first quarter. Workers who have lost their jobs account for most of the increase in unemployment in these three months. The small increases in the other categories are probably the result largely of the longer search for jobs caused by competition with the flood of recent job losers.

3. One might argue that the increase in unemployment in these groups was caused by a decline in job openings. This argument is refuted by the data on the duration of unemployment, which suggest, if anything, that these individuals found jobs faster than is normal. 
Table 3. Unemployment, by Source, September 1968-March 1969 and September 1969-March 1970

Thousands of persons, without seasonal adjustment

\begin{tabular}{lrrrrrrrr}
\hline \multicolumn{1}{c}{ Month } & \multicolumn{2}{c}{ Lost job } & \multicolumn{2}{c}{ Left last job } & \multicolumn{2}{c}{$\begin{array}{c}\text { Reentered } \\
\text { labor force }\end{array}$} & \multicolumn{2}{c}{$\begin{array}{c}\text { Entered } \\
\text { labor force }\end{array}$} \\
\hline & 1968 & 1969 & 1968 & 1969 & 1968 & 1969 & 1968 & 1969 \\
September & 841 & 823 & 497 & 586 & 903 & 1,105 & 366 & 445 \\
October & 857 & 882 & 430 & 451 & 873 & 1,093 & 351 & 414 \\
November & 866 & 939 & 415 & 421 & 900 & 1,011 & 375 & 339 \\
December & 914 & 1,133 & 339 & 378 & 822 & 825 & 343 & 292 \\
& 1969 & 1970 & 1969 & 1970 & 1969 & 1970 & 1969 & 1970 \\
January & 1,266 & 1,595 & 463 & 485 & 881 & 999 & 265 & 328 \\
February & 1,245 & 1,787 & 409 & 473 & 947 & 1,158 & 323 & 377 \\
March & 1,186 & 1,797 & 391 & 441 & 869 & 1,143 & 301 & 351 \\
\hline
\end{tabular}

Source: Enployment and Earnings, various issues.

To summarize, what evidence there is in the detailed data on the labor force suggests little overall slackening in the demand for labor until this winter. Since then, the reduction in demand has been relatively concentrated in particular classes of workers. Thus far, minority members of the labor force have not suffered a proportionate rise in unemployment. But this is likely to reflect the industrial concentration of the slowdown to date rather than any substantial improvement in the basic job security of these workers.

\section{Discussion}

IT WAS GENERALLY AGREED that the slower growth of production in the second half of 1968 and the first half of 1969 had an unexpectedly mild impact on the strength of demand for labor. However, several participants questioned Robert Hall's interpretation of developments during the second half of 1969. Lawrence Klein and Goeffrey Moore both pointed to other labor market indicators that had weakened to some extent during the fall of 1969. These included payroll employment, average hours worked, insured unemployment, help wanted advertising, and the quit rate. All of 
these seemed to precede the moderation in the labor force data that Hall had analyzed.

Alan Greenspan noted the strong increase in the female participation rate during 1969, which he considered to be one of the most interesting aspects of labor force developments. He felt that the demand for female labor-especially in the service industries-was still strong. Hall and Robert J. Gordon both suggested that the increased participation of women, who typically work shorter hours, is probably part of the explanation for the recent decline in average hours worked. 